Proc. Estonian Acad. Sci. Biol. Ecol., 2005, 54, 4, 342-346

\title{
State-of-the-art: the use of Enchytraeidae (Oligochaeta) as test and indicator organisms in standardized ecotoxicological tests
}

\author{
Jörg Römbke*, Stephan Jänsch, and Thomas Moser \\ ECT Oekotoxikologie GmbH, Boettgerstr. 2-14, D-65439 Flörsheim, Germany \\ Received 12 October 2004, in revised form 22 February 2005

\begin{abstract}
Despite the fact that enchytraeids have been used in ecotoxicological studies for at least three decades, their use has been formalized in standardized guidelines only recently. When including some guideline proposals, all possible investigation levels (laboratory, semi-field (model ecosystems), and field) as well as several endpoints (acute and chronic toxicity, bioaccumulation, and composition of the enchytraeids community) are covered. In this contribution an overview about these activities is given, covering the testing of single chemicals (e.g. pesticides) as well as the assessment of contaminated land. Except lumbricid earthworms no other group of soil organisms is represented so well in terrestrial ecotoxicology.
\end{abstract}

Key words: laboratory, semi-field, field, monitoring, acute, chronic, bioaccumulation, Oligochaeta.

\section{INTRODUCTION}

In terrestrial ecotoxicology, the focus has been very much on earthworms, as these large animals are ecologically important and are easy to handle (Paoletti 1999). However, the need for an extension of the battery of tests has become obvious since earthworms alone cannot be representative for the complex community of soil invertebrates. Besides microarthropods (in particular collembolans) Enchytraeidae belong to the group of potential test organisms due to their ecological relevance. Despite the fact that enchytraeids have been used in ecotoxicological studies for at least three decades, it is only recently that their use has been formalized in standardized guidelines (Römbke 2003). When including some guideline proposals, all possible investigation levels (laboratory, semi-field (model ecosystems), and

* Corresponding author, J-Roembke@ect.de 
field) as well as several endpoints (acute and chronic toxicity, bioaccumulation, and dominance spectrum) are covered. In this contribution an overview about these activities in standardized tests is given. These tests are required for legally and economically important purposes such as the registration of pesticides or the notification of chemicals in the European Union (e.g. EU 1991). Without standardization, test results are not comparable and thus cannot be accepted by the respective authorities.

\section{OVERVIEW OF STANDARDIZED TESTS}

\section{Laboratory level}

A reproduction test was adopted by ISO (2003), OECD (2004), and ASTM (2004) for the assessment of chemicals as well as for contaminated soils. Several species of the genus Enchytraeus can be used in this test (Table 1).

Despite the fact that many bioaccumulation studies have been performed with earthworms as representatives of soil invertebrates, no standard guideline is available. Therefore, such a test for measuring uptake and elimination of (mainly labelled) ${ }^{14} \mathrm{C}$ chemicals by oligochaetes from soil has been drafted for OECD (Table 2). A ring-test is planned for 2005.

Table 1. Enchytraeid Reproduction Test (ERT)

\begin{tabular}{ll}
\hline Guideline & OECD 220 (2004), ISO 16387 (2003) \\
Species & Enchytraeus albidus, E. crypticus, E. luxuriosus, etc. \\
Substrate & OECD artificial soil or field soils (pH not less than 4.5) \\
Test conditions & $20 \pm 2{ }^{\circ} \mathrm{C}$; light: $16 / 8$ h light/dark; food: rolled oats; humidity: $40-60 \%$ of \\
& the maximum water holding capacity (WHC) \\
Duration & 42 days (E. albidus); 28 days (other species) \\
Parameter & Mortality of adults, reproduction (No. of juveniles) \\
Design & NOEC, EC 50, limit test \\
Validity (control) & $\begin{array}{l}\text { Mortality }<20 \% ; \text { No. of juveniles }>25 ; \text { coefficient of variation (juveniles) } \\
\end{array}$ \\
& $<50 \%$
\end{tabular}

Table 2. Bioaccumulation: Soil Test using terrestrial Oligochaetes

\begin{tabular}{ll}
\hline Guideline & Proposal acc. to OECD format (Bruns et al. 2001) \\
Species & Enchytraeus albidus, E. luxuriosus \\
Substrate & OECD artificial soil or field soils (e.g. LUFA standard soil 2.2) \\
Test conditions & $20 \pm 2^{\circ} \mathrm{C}$; light: permanent; food (once): rolled oats \\
Duration & $28-42$ days (uptake and elimination period) \\
Parameter & Bioaccumulation (BAF) or biota-soil accumulation factor (BSAF, lipid- \\
& normalized)
\end{tabular}




\section{Semi-field level}

Enchytraeids have been used often in microcosm studies with different purposes. However, a standardized proposal is available only for one method: The Terrestrial Model Ecosystem (TME; Table 3). Recently, it was validated in an inter-laboratory comparison study (Moser et al. 2004).

\section{Field level}

In the context of testing the effects of chemicals in the field as well as for the biological classification of soils it is necessary to use a standardized method for the sampling of enchytraeids (Jänsch \& Römbke 2003). Together with comparable methods for earthworms, nematodes, and microarthropods a guideline is currently being standardized (ISO; Table 4).

Table 3. Terrestrial Model Ecosystem (TME)

\begin{tabular}{ll}
\hline Guideline & Proposal acc. to OECD format (Knacker et al. 2004) \\
Species & Natural enchytraeid field community \\
Substrate & Natural field soils \\
Test conditions & $20 \pm 2^{\circ} \mathrm{C} ; 16 / 8 \mathrm{~h}$ light/dark cycle; artificial rain \\
Duration & Variable; e.g. 16 weeks (depending on the properties of the soil and those of \\
& the test substance) \\
Parameter & Abundance, species composition of the enchytraeid community \\
Design & NOEC, $\mathrm{EC}_{50}$, limit test
\end{tabular}

Table 4. Sampling and soil extraction of enchytraeids

\begin{tabular}{ll}
\hline $\begin{array}{l}\text { Guideline } \\
\text { Species }\end{array}$ & ISO draft guideline No. 23611-3 (ISO 2004) \\
Substrate & Natural enchytraeid field community \\
Method & Natural field soils \\
& $\begin{array}{c}\text { Soil sampling with a soil corer in the field; extraction of the worms in a } \\
\text { simple wet-extraction method; microscopical species determination }\end{array}$ \\
$\begin{array}{l}\text { Duration } \\
\text { Parameter (potential) }\end{array}$ & Abundance, species composition, dominance spectrum
\end{tabular}




\section{DISCUSSION}

This overview exemplifies that enchytraeids can be used on all levels of ecotoxicological testing. Besides a standard laboratory method, proposals close to standardization are available for semi-field, field, and bioaccumulation tests. Such a broad coverage of a group of soil invertebrates is very rare in ecotoxicology; in fact, a similar number of test methods is only available for lumbricid earthworms. Therefore, the use of the unspectacular but ecologically relevant Enchytraeidae in soil ecotoxicology is recommended.

\section{ACKNOWLEDGEMENTS}

The work reported here was sponsored by the German Federal Environmental Agency and by the European Union.

\section{REFERENCES}

ASTM (American Society for Testing and Materials). 2004. Standard guide for conducting laboratory soil toxicity or bioaccumulation tests with the lumbricid earthworm Eisenia fetida and the enchytraeid potworm Enchytraeus albidus. In Annual Book of ASTM Standards, 1676, pp. 1-26.

Bruns, E., Egeler, Ph., Römbke, J., Scheffczyk, A. \& Spörlein, P. 2001. Bioaccumulation of lindane and hexachlorobenzene by the oligochaetes Enchytraeus luxuriosus and Enchytraeus albidus (Enchytraeidae, Oligochaeta, Annelida). Hydrobiologia, 463, 185-197.

EU (European Union). 1991. Council Directive concerning the placing of plant protection products on the market No. 91/414/EEC. Brussels.

ISO (International Organization for Standardization). 2003. Soil quality - effects of pollutants on Enchytraeidae (Enchytraeus sp.). Determination of effects on reproduction and survival. ISO 16387. Genève.

ISO (International Organization for Standardization). 2004. Draft: Soil quality - sampling of soil invertebrates. Part 2: Sampling and extraction of enchytraeids. ISO 23611-3. Genève.

Jänsch, S. \& Römbke, J. 2003. Ecological characterization of selected enchytraeid species (Enchytraeidae, Oligochaeta) - a literature research. Newsl. Enchytraeidae, 8, 57-68. (Wageningen University, The Netherlands.)

Knacker, T., van Gestel, C. A. M., Jones, S. E., Soares, A. M. V. M., Schallnass, H.-J., Förster, B. \& Edwards, C. A. 2004. Ring-testing and field-validation of a Terrestrial Model Ecosystem (TME) - an instrument for testing potentially harmful substances: conceptual approach and study design. Ecotoxicology, 13, 9-28.

Moser, T., van Gestel, C. A. M., Jones, S. E., Koolhaas, J. E., Rodrigues, J. M. L. \& Römbke, J. 2004. Ring-testing and field-validation of a Terrestrial Model Ecosystem (TME) - an instrument for testing potentially harmful substances: effects of Carbendazim on enchytraeids. Ecotoxicology, 13, 85-99.

OECD (Organisation for Economic Co-Operation and Development). 2004. Guideline for testing of chemicals No. 220. Enchytraeidae reproduction test. Paris. 
Paoletti, M. G. 1999. The role of earthworms for assessment of sustainability and as bioindicators. Agricult., Ecosyst. \& Environ., 74, 137-155.

Römbke, J. 2003. Ecotoxicological laboratory tests with enchytraeids: a review. Pedobiologia, 47, 607-616.

\section{Valgeliimuklaste kasutamine test- ja indikaatororganismidena ökotoksikoloogias: hetkeseis}

Jörg Römbke, Stephan Jänsch ja Thomas Moser

Valgeliimuklasi on ökotoksikoloogias kasutatud vähemalt kolm aastakümmet, aga standardjuhendeid on selleks vormistatud alles hiljuti. Juhendites on vaja ette näha mitmesuguseid uurimistasemeid (laborikatse, mudelkooslus ja välitingimused) ja eesmärke (akuutne ja krooniline toksilisus, bioakumulatsioon, valgeliimuklaste liigiline koosseis). Käesolevas töös on antud ülevaade sellealasest tegevusest, mis puutub üksikute kemikaalide (näiteks pestitsiidide) testimisse ja mulla reostatuse hindamisse. Peale vihmausside pole ükski mullaorganismide rühm maismaa ökotoksikoloogias seni paremini esindatud kui valgeliimuklased. 